TI 2011-119/3

Tinbergen Institute Discussion Paper

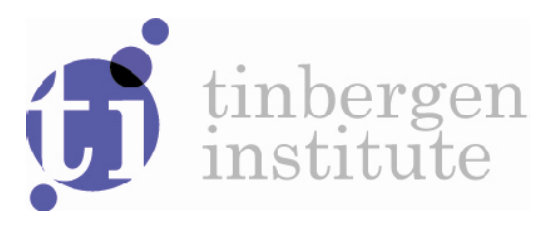

\title{
Knowledge Virtualization and Local Connectedness among Smart High- tech Companies
}

Marina van Geenhuizen'

Peter Nijkamp 2

' Faculty of Technology, Policy and Management, Delft University of Technology, Delft, The Netherlands;

2 Faculty of Economics and Business Administration, VU University Amsterdam, The Netherlands. 
Tinbergen Institute is the graduate school and research institute in economics of Erasmus University Rotterdam, the University of Amsterdam and VU University Amsterdam.

More TI discussion papers can be downloaded at http://www.tinbergen.nl

Tinbergen Institute has two locations:

Tinbergen Institute Amsterdam

Gustav Mahlerplein 117

1082 MS Amsterdam

The Netherlands

Tel.: +31(0)205251600

Tinbergen Institute Rotterdam

Burg. Oudlaan 50

3062 PA Rotterdam

The Netherlands

Tel.: +31(0)10 4088900

Fax: $+31(0) 104089031$

Duisenberg school of finance is a collaboration of the Dutch financial sector and universities, with the ambition to support innovative research and offer top quality academic education in core areas of finance.

DSF research papers can be downloaded at: http://www.dsf.nl/

Duisenberg school of finance

Gustav Mahlerplein 117

1082 MS Amsterdam

The Netherlands

Tel.: +31(0)20 5258579 


\title{
KNOWLEDGE VIRTUALIZATION AND LOCAL CONNECTEDNESS AMONG YOUNG GLOBALIZED HIGH-TECH COMPANIES
}

\begin{tabular}{|l|l|}
\hline Marina van Geenhuizen & Peter Nijkamp \\
Faculty of Technology, Policy and Management & Faculty of Economics and Business Administration \\
Delft University of Technology, Delft & Vrije Universiteit Amsterdam \\
The Netherlands & The Netherlands \\
m.s.vangeenhuizen@tudelft.nl & p.nijkamp@vu.nl \\
& \\
\hline
\end{tabular}

\begin{abstract}
Smart high-tech companies are characterized by knowledge intensity and open innovation. Even when these companies emerge in spatial clusters or dense urban places, they may utilize knowledge networks on a global scale. However, there is not much insight into the factors that shape knowledge networks, the role of virtualization herein and the impact of on global knowledge sourcing on local connectedness. This paper seeks to fill these gaps in understanding, by drawing on a selected sample of young high-technology companies in the Netherlands and application of rough set analysis to identify homogeneous categories of companies in the highly differentiated segment of young high-tech companies. The outcomes suggest that employing mainly local and employing mainly global knowledge networks coexist in city-regions, and that only part of the globalized companies are losing local connectedness, particularly those involved in co-creation with global customers and those acting as learning partners of multinational corporations ('reverse' knowledge transfer). Factors counteracting a weakening of local connectedness are specific local knowledge relationships and the strategy of developing local/regional customer markets.
\end{abstract}

Key words: high-technology companies, open innovation, knowledge networks, strategic focus, dynamic capabilities, virtualization, local connectedness, rough set analysis.

Pn393mvg 


\section{In Search of Knowledge in Open Networks}

It is widely acknowledged that since the turn of the century innovation and problemsolving have become more open processes. Open innovation is believed to provide advantages of acceleration of market introduction of new products, processes etc. and also of cost reduction, due to sharing (part of) important knowledge with other organizations. Single companies cannot innovate in isolation; learning processes evolve through interaction with a wide range of other organizations, like suppliers, customers, competitors, multinational corporations, universities, venture capitalists, etc. (Chesbrough et al., 2006; Laursen and Salter, 2006).

In spatial innovation studies, the emergence of open innovation and supporting information and communication technology has caused heated debates on the role of physical distance in the space-economy since the early 2000s. Doubts on the role of local proximity in shaping knowledge relations in dense urban places were based upon at least three arguments. First, the intimate relation between local proximity and tacit knowledge transfer has been criticized based upon the idea that tacit knowledge can also be transferred over distances in global networks by travelling of persons, provided that the contextual knowledge necessary for understanding, is present, like in global communities of practice and global research alliances (for example, Gertler, 2003). In addition, local proximity per se is not sufficient in generating tacit knowledge transfer and localized learning favourable for innovation (see, for example, Boschma, 2005).

Secondly, the general globalization of economic activity and the increased specialisation in innovation seem to exclude that all major components of knowledge necessary for innovation and problem-solving are found in one and the same place (Simmie, 2003; Torre, 2008). This observation connects with a third argument, derived from the entrepreneurial perspective on knowledge networking in open systems (Bathelt et al., 2004; Best, 2001; van Geenhuizen, 2008a; Martin and Sunley, 2002; Storper and Scott, 2009). High-technology companies don't search for local knowledge but search for the best available knowledge in the frame of their competitive edge, and this happens on a continuum running from local to global places, eventually leading to distributed innovation. In addition, companies may be different in innovation strategies and in learning capabilities, the latter including companies' different sense of cognitive proximity and different absorptive capacity (Cohen and Levinthal, 1990; Guiliani and Bell, 2005; Jong and Freel, 2010; Taheri and van Geenhuizen, 2011). Relatively new is the emphasis on the specificities of sectors in learning behaviour offering an explanation why companies in some sectors derive knowledge mainly from local sources and others from global sources (Asheim et al., 2007; Tidd et al., 2005). Accordingly, companies 
search for knowledge on various scales dependent on availability of the best knowledge and dependent on their sector, strategy and capabilities.

Indeed, new empirical evidence has increasingly cast doubt on a pre-eminent role of localized knowledge networking. Examples can be found in studies on research collaboration measured through publications in journals and patent citations (Johnson et al., 2006) and in studies of broader knowledge relations in the most clustered hightechnology sectors, such as biotechnology. Coenen et al. (2004), Lawton-Smith (2004), McKelvey et al. (2004), and Mytelka (2004) observed a minor importance of local knowledge sources, or at least an equal importance of local and long distance knowledge relationships. Also, Gertler and Levitte (2005) questioned the pervasiveness of the local in biotechnology innovation. In studying petrochemical industry (Cumbers et al., 2003) and optoelectronics industry (Hendry and Brown, 2006) other authors arrived at similar results and question marks. Aside from this, there is an extensive literature on a specific segment of small high-tech companies, the so-called born-globals. These companies show a very rapid and intense internationalization immediately after their take-off (e.g., Andersson and Wictor, 2003; Jones et al., 2009; Rialp et al., 2005). In addition, small high-tech firms may be acquired by large international companies (MNCs) just for their knowledge and innovation potential. Learning by MNCs from their foreign subsidiaries ('reverse' knowledge transfers) is getting a steady attention in the literature (e.g., Ambos et al., 2006; Frost, 2001; Frost and Zhou, 2005).

The progress in information- and communication technologies (ICT) is usually regarded as an important enabling factor in building global knowledge relations. In the recent past, advances concerning network, computational and imaging improvements, have combined to realize more sophisticated software to support control over processes on a distance, to support virtual decision-making and design, and virtual experimentation and simulation in distributed teams, and to increase computing capacity by grid- or cloud-computing. There has been an increase in complexity of the knowledge that is transferred and produced electronically, as well as of the complexity of tasks carried out virtually. In the near future, the ceiling may be reached in what can be virtualized, due to technical shortcomings causing communication and management problems, and due to regulation limitations. However, virtualization may also open new types of knowledge, like richer forms of tacit knowledge and richer ways of problem-solving, enabled by virtual design and virtual simulation and experimentation (Becker et al., 2005; Vaccaro et al., 2009).

Despite the growing number of studies emphasizing the role of open innovation and global knowledge networks in an entrepreneurial perspective, few authors have attempted to better understand how predominantly global knowledge networks are being shaped and structured, and to what extent this is supported by virtualization. Exceptions with regard to virtualization and related management issues are Chudoba et al. (2005); Ebrahim et al. 
(2009); Hinds and Kiesler (2002); Joshi et al. (2009); Martins et al. (2004); and Sapsed et al. (2005). Exceptions with regard to virtualization and innovation are, for example, Becker et al. (2005) and Vaccaro et al. (2009, 2010). In addition, there is only small understanding of how global knowledge interaction affects the companies' networks in the local production system. The changes that occur in local supplier- and customer relations and in local personal networks when the company gains mainly global knowledge input, have remained almost unknown to date. There may be a loss of local connectedness of the companies, or conversely, there may be a strengthening, for example, if particular local relationships benefit from new global knowledge through local diffusion (e.g. Bathelt et al., 2004). The study by DeMartino et al. (2006) is one of the first studies dealing with such impacts, but attention is currently growing, particularly based on negative dynamics fragmentation of production and outsourcing of manufacturing abroad - in Italian industrial districts, e.g. addressed by Amighini and Rabellotti (2006). In this frame, in April 2011, The Economist raised the issue as a serious one, under the title "Clusters flustered”.

In an attempt to fill the above knowledge gaps, this study takes an entrepreneurial perspective, in which globally shaped knowledge networks are analysed using theoretical notions on companies' strategies, capabilities and virtualization needs, and theoretical notions on the position in multinational corporations (MNCs) (e.g. Dicken, 2004; Frost, 2005). The contribution is particularly in highlighting the connection between adaptations on different spatial level (local and global) (Bunnell and Coe, 2001), that is impacts of various types of global learning on local connectedness.

Using a method from artificial intelligence, viz. rough set analysis and dealing with a small sample of young, high-tech companies in the Netherlands, the study addresses the following questions: (1) which factors are shaping the geographical scale of knowledge networks and to what extent is global knowledge networking in innovation supported by virtualization, and (2) how are changing global knowledge networks affecting local connectedness of companies? Compared with previous work (Van Geenhuizen, 2008a, 2008b) more in-depth results have been gained, due to a stronger emphasis on virtualization and on influence of different types of global knowledge relations (MNC context) on local connectedness.

The structure of the paper is as follows. It starts with a brief presentation of the analytical framework, particularly focusing on virtualization, (Section 2) and a discussion of the research design (Section 3). This is followed by an examination of the outcomes of a learning experiment on factors shaping global knowledge networks and supporting roles of virtualization (Section 4). A discussion of changes in local connectedness is next provided (Section 5). The conclusion gives an evaluation of the results and some future research lines (Section 6). 


\section{An Entrepreneurial and Virtualization Perspective}

\subsection{Entrepreneurial perspective}

The analysis of learning in companies with an emphasis on internal factors is relatively new (see, for example, Martin and Sunley, 2002). We elaborate an analytical framework in which an entrepreneurial perspective is adopted with a focus on strategies and dynamic capabilities. In general, companies develop strategies to seize opportunities in particular product markets (sectors) and to maintain competitive edge, for example, in product uniqueness (innovation), cost-reduction, or expanding in new geographic markets. Virtualization may support many of these strategic changes, like cost-reduction in communication, efficiency gains in co-design in new product development, and the establishment of virtual teams in geographic market expansion. Different strategies require a different use of resources that companies achieve through own development or networking with other companies (Barney, 1991; Barney and Clark, 2007; Lockett and Thompson, 2001). For example, a research company in biotechnology requires more knowledge and investment capital compared to local services companies in biotechnology. We distinguish between two components in a simplified analytical framework, i.e. strategy and dynamic internal capabilities.

Our analysis of strategy is established on three theoretical attributes, i.e. main activity, innovation intensity, and spatial focus in the overall strategy. The main activity (sector) is included because of differences in needs for knowledge and different modes of learning, like between science-based companies and engineering (customer-oriented) companies (Asheim et al., 2007). In a similar vein, innovation intensity is seen as important because the stronger the intensity, the larger the chance that the best knowledge is not locally available but just in a few places across the globe (for example, Nooteboom, 2000). With regard to the overall strategy, it is important to mention specific young innovative companies that employ an internationalisation strategy actively from their start and build competitive advantage from resources and sales of outputs in multiple countries, the socalled born-globals (Andersson and Wictor, 2003; Rialp et al., 2005). These tend to be relatively specialized and are endowed with the capability to access $R \& D$ channels through close collaboration with global partners. By contrast, other young companies develop an international strategy as a stepwise, gradual process in which they expand their customer markets and gain capabilities over time in dealing with global partners (Forsgren, 2002; Johanson and Vahlne, 1977; Madsen and Servais, 1997).

Young high-tech companies in cities/regions may also be established or acquired by foreign (multinational) corporations (MNCs). In such a situation the strategy of these local companies often depends on their role in the production organization of the MNC. We mention two of them: to increase regional market share and to produce knowledge. The 
first is well-known in the history of MNC development, the last - meaning that MNCs learn from their foreign subsidiaries eventually in R\&D co-practice - emerged later and is named 'reverse' knowledge transfer in some studies (e.g. Ambos et al., 2006; Dunning, 2000; Frost 2001; Frost and Zhou, 2005).

The capabilities that are generally relevant in international activities are those through which a company can enter into alliances and access partners' resources and, accordingly, can overcome resource deficiencies (Chetty and Wilson, 2003; Dana, 2001). These capabilities rest on two company characteristics, that is, previous experience and internal intangible assets. Previous experience encompasses management experience of entrepreneurs, e.g. in the case of young corporate spin-off companies or subsidiary of a foreign company. Intangible assets include, for example, relational capability enabling to select the right network partners, and absorptive capacity allowing to recognize the value of new external knowledge and to identify, acquire and absorb it (Cohen and Levinthal, 1990; Zahra and George, 2002). The influence of different dynamic capabilities and the resulting differences in cumulative learning processes over time may contribute to heterogeneity between companies in the same urban places and clusters (for example, Lichtenthaler and Lichtenthaler, 2009; Teece, 2007). Dynamic capabilities are rooted in high-performance routines within companies, and are embedded in their processes while being conditioned by companies’ past history.

Networks may be seen as specific external sources of resources, and employing of them has become quite common in the business world since the late 1970s (for example, Borgatti and Foster, 2003; Hoang and Antoncic, 2003). Since the early 2000s, the dimensions of open innovation and the virtues of different degrees of open innovation have been highlighted (Chesbrough, 2006; Dahlander and Gann, 2010; Vrande et al., 2008). Of particular interest in this study are learning networks - eventually co-creation in innovation - and management networks. Small high-technology companies may gain costadvantages from open and flexible types of learning or from contract-based research partnerships because these give them access to a varied field of knowledge without investing in all of them (Roijakkers and Hagedoorn, 2006). Companies establish networks or remain participating in existing networks if the perceived benefits outweigh the perceived costs. Networks and the interaction in these networks may be virtual in varying degrees.

\subsection{A virtualization perspective}

We conceive virtualization at an abstract level as making physical activities, relations and goods more virtual, exemplified by the following activities: communication, meetings, management, knowledge interaction in innovation (data-mining, virtual design and virtual simulation and experimentation, etc.). Virtual teams exist when the members of a group in geographically dispersed places interact with the aim to accomplish common 
goals within one organisation (Ebrahim et al., 2009; Martins et al., 2004). Global virtual teams utilize a set of collaborative interactive tools like accompanied surfing, document reviewing, chat, discussion groups, etc. A crucial condition in the exchange of diffuse and tacit knowledge is a similar social (cultural) context of the partners involved, determining a proper understanding and interpretation of the codified knowledge (e.g. Bolisani and Scarso, 2011) and a sufficient management of virtual teams (e.g., Solomon, 2001).

The advantages of virtualization have also become more clear in the past years, including some financially attractive aspects. It provides an effective mechanism for reducing the increased travel costs, costs of coordination, and costs associated with bringing together geographically, temporally, and functionally dispersed persons to work on a common task (Lipnack and Stamps, 1997). Virtualization in innovation has become more attractive because of reducing costs of product development and increasing its speed (Becker et al., 2005). Table 1 lists the major potential benefits of virtualization in a global context and evaluates these advantages in the context of knowledge exchange and innovation.

Opportunities of virtual teams have started to be considered more significant in knowledge production and exchange, not only because it is necessary to tap the best knowledge resources (wherever available), but also because the company of research activity itself is often international, concerning e.g. customer relations and supplier relations (Hinds and Kiesler, 2002). Researchers are geographically distributed, in part because necessary resources - human resources, expertise, diversity of perspectives, timezones - are distributed geographically (point 1-3) (Table 1). In addition, global virtual teams are able to respond flexibly to local changes in development and design thereby improving market access and marketing (point 4).

Next are various opportunities from virtual teams (not necessarily global) connected with the nature of communication using ICT (point 5-8). An increased fluency of data transfer seems one of the important successes in particular situations. If data and knowledge being transferred is somehow best understood in the form of figures and any other formal presentation structure rather than verbal form, than the technology can give its best performance to translate the data into the appropriate and suitable information. In addition, communication may be more thoughtful. This connects with the argument that virtualization sometimes could be more effective than conventional work types with faceto-face interaction when there are cultural or personal differences because employees do not have to see and perceive other members personally and being influenced by their cultural background (Potter and Balthazard, 2002).

There is also an increasing awareness on advantages of virtualization in the practice of innovation using virtual tools (Becker et al., 2005; Vaccaro et al., 2009, 2010). The interpretation of results of virtual simulation and experimentation tends to increase the 
amount of tacit knowledge in innovation practices due to a larger number of simulations per time unit and an increased precision of design practice following from using multiscale and multidimensional representations.

\section{Table 1 Opportunities from virtualization}

\begin{tabular}{|l|l|}
\hline $\begin{array}{l}\text { 1.Utilization of unique human } \\
\text { resources (talent) and of unique } \\
\text { knowledge/expertise dispersed in the } \\
\text { world }\end{array}$ & Rolds true for many situations \\
\hline $\begin{array}{l}\text { 2.Utilization of diverse perspectives } \\
\text { and turning this diversity into new } \\
\text { thoughts potentially, leading to more } \\
\text { innovation }\end{array}$ & $\begin{array}{l}\text { Holds true for many situations (as soon as } \\
\text { misunderstandings have been overcome) }\end{array}$ \\
\hline $\begin{array}{l}\text { 3.Utilization of different time-zones to } \\
\text { derive continuity in service supply and } \\
\text { continuity in experimentation }\end{array}$ & $\begin{array}{l}\text { Limited to sectors that work around the clock in } \\
\text { service supply, and limited to participation of } \\
\text { scientists or customers in experiments with a certain } \\
\text { time-length and successive steps }\end{array}$ \\
\hline $\begin{array}{l}\text { 4.Increase of flexibility and } \\
\text { responsiveness to local customers } \\
\text { across the world in development }\end{array}$ & $\begin{array}{l}\text { Limited to development of products build on different } \\
\text { and changing local customer specification, leading to } \\
\text { improvement of market access and marketing }\end{array}$ \\
\hline $\begin{array}{l}\text { 5.Increase of fluency of information } \\
\text { (data) transfer, leading to higher } \\
\text { efficiency of this transfer }\end{array}$ & $\begin{array}{l}\text { Particularly true for information that is best understood } \\
\text { through formal presentation, and for situations in } \\
\text { which cultural or personal differences may disturb } \\
\text { face-to-face interaction }\end{array}$ \\
\hline $\begin{array}{l}\text { 6.More thoughtful responses, leading } \\
\text { to higher efficiency of communication }\end{array}$ & $\begin{array}{l}\text { Holds true for text-based technologies allowing team } \\
\text { members spending more time and at convenient points } \\
\text { in time to respond, leading to more substantial } \\
\text { responses (compared to face-to-face and telephone) }\end{array}$ \\
\hline $\begin{array}{l}\text { 7.Richer results, due to more and } \\
\text { unique tacit knowledge creation in } \\
\text { innovation practice }\end{array}$ & $\begin{array}{l}\text { Use of virtual design and experimentation enables } \\
\text { more simulations per unit time and increased precision } \\
\text { (multi-dimensional representation), thereby producing } \\
\text { much richer tacit knowledge than traditionally. }\end{array}$ \\
\hline $\begin{array}{l}\text { 8.Richer ways of problem-solving } \\
\text { the of virtual simulation and experimentation changes } \\
\text { the kind of problem-solving, adding 'abduction' to } \\
\text { conventional deduction and induction. Knowledge } \\
\text { sources used aside from conventional ones, include for } \\
\text { example intuition and imagination. }\end{array}$ \\
\hline
\end{tabular}

Source: based on literature search by the first author. 
In addition, the simultaneous use of ICT, especially 3D-CAD including specific tools, tends to enhance creation of new tacit knowledge through social interaction in virtual teams. Moreover, virtual simulation and experimentation may bring about more richer innovation results. New ways of problem-solving may be added to conventional ones through dealing with problems that are unstructured and drawing on implicit assumptions, intuition, experiential knowledge, imagination, etc.

In general, the set of virtual modes of interaction and innovation selected by companies depends on the trade-off between goals and benefits achieved in the particular subject matter and costs involved (Sapsed et al., 2005). In addition, the business value of information and communication technology and tools, particularly the more comprehensive ones, depends on the willingness of companies to redesign their ways of problem-solving and adapt organizational processes. The latter conditions match with ample evidence that introducing new technology in general triggers changes in the way tasks are accomplished and processes are structured (Becker et al., 2005). This situation might hamper an easy adoption of virtual simulation and experimentation. But overall, we may conclude that virtualization has opened many potential advantages in knowledge exchange and innovation, and tends to act even stronger than traditional face-to-face and paper-based communication and innovation.

Despite the above opportunities, global virtual teams encounter various situations that call for improvement due to a number of dispersion and communication limitations. Note that some limitations depend on the level of virtualization - extent to which team members use ICTs in interaction and common tasks (Jong et al., 2008). In addition, virtual teams may initially suffer from shortcomings but they may also improve to a stronger degree than non-virtual teams (Pazos and Beruvides, 2011). The limitations can be summarized as follows (e.g., Badrinarayanan and Arnett, 2008; Cramton and Orvis, 2003; Jarvenpaa et al., 1998). First, distance tends to make it more difficult for dispersed team members to develop shared understanding and to work around company issues as easily as co-located team members do, simply because they lack the 'face' time. Misunderstanding may be one of the consequences. Among dispersed team members, local priorities often exert more influence than the larger organization's pressures. In other words, lack of actual human contact may depersonalize the interaction experience such that over time morale, spirit, and commitment can falter. Maintaining common goals, including coordination and cohesiveness of the team and project control, may thus become problematic. In addition, trust as one of the major required conditions, cannot be created or refreshed electronically. However, trust can be refreshed in well-planned face-to-face meetings (Maznovsky and Chudoba, 2000). The previous circumstances have raised the issue of leadership and new methods of supervision and control (e.g., Joshi et al., 2009). 
As a second set of problematic situations, we mention that using ICT tools can create many practical obstacles. Effectiveness of the tools depends on the quality of local infrastructures, including the networks. Speed of international connectivity/interactions which are not the same in different locations can become a problem. Moreover, collaborative interactive tools are sometimes difficult to handle and can change rapidly. This situation means that virtual team members more so than members of traditional teams must master current technologies and develop an ability to integrate new technology (particularly software tools) as these are introduced. We also need to mention that in many cases of virtual interaction in innovation (co-design, co-testing, remote calibration and control, simulation and experimentation) there is a shortage in regulations, concerning access to databases and computing power, intellectual ownership, responsibility and liability, and protection and safety.

\subsection{Impacts on local connectedness}

A global orientation in knowledge gaining may cause companies - in next steps of their development - to become geographically dispersed. The latter may occur if virtualization reaches its 'ceiling' and a partial relocation of companies is cost-effective. This scenario is currently taking place in various industrial districts in Italy, thereby reducing coherence and connectedness within the local production system (e.g., Amighini and Rabellotti, 2006). In contrast, a positive scenario may be true where global knowledge networks (global pipelines) interact with local networks and make them stronger (Bathelt et al., 2004). Whether the latter occurs, is also dependent on various other conditions. The existence of global pipelines is not a guarantee for better performance in learning, the quality of the connecting companies as 'gate-keepers' and a high quality of local buzz, in other words, efficiently working local diffusion mechanisms, seem to be key (Graf and Krüger, 2011; Morrison et al., 2010).

\section{Research Design and Methodology}

\subsection{Research setting and sampling}

The study used a multiple case study approach of 21 carefully selected companies which were personally interviewed. The selection aimed at representation of major categories of young, urban innovators in the Netherlands, for example, companies endowed with different organizational capability and different functions in global knowledge production (spin-offs versus independently established companies, and foreign subsidiaries), companies active in different types of innovation (highly innovative in bringing global break-through innovations to market versus incrementally innovative in short projects in response to customer demand) and active in different sectors going along with different learning modes (science-based, engineering/customer-based, and creative interactive local 
learning, and with a different acquaintance with virtual means in the sector (Asheim et al., 2007; Sapsed et al., 2005). The study was limited to advanced optronics instruments (a mix of optics and micro-electronics) and other advanced micro-electronics industry; biotechnology representing research and standard and advanced services; and different ICT services (telecommunication services and advanced ICT services).

\subsection{Rough set analysis: principles}

Rough set analysis was used as a 'causal' approach producing a set of decision rules on the occurrence of local/regional and global knowledge networks. In addition, these rules and outcomes were evaluated for implications concerning virtualization in knowledge activity and local connectedness of companies. So the aim was to derive some general testable propositions from a limited number of cases.

Rough set analysis was applied because of its match with small samples, a low level of measurement of some data (i.e. categorical) and a somewhat fuzzy character of the data (e.g. Pawlak, 1991, 2001; for details, see Polkowski and Skowron, 1998, for a new approach, see Klopotek and Wierzchon, 2009). A main advantage is that in rough set analysis - unlike more conventional methods such as multiple regression analysis and discrete choice models - only one assumption is made about the data, i.e. that the value of the determining factors can be categorized. Rough set analysis has increased in popularity in the investigation of company behaviour, like acquisition, failure (bankruptcy), market strategy and location-boundedness (for details, see, van Geenhuizen and Nijkamp, 2007, and Soetanto and van Geenhuizen, 2007).

In traditional rough set analysis used in this study the data are presented in an information table, that is, a matrix in which rows are labelled by objects (in this study: companies) and columns are labelled by attributes (variables) (Table 2). Objects are arranged on the basis of their condition attributes (C) and decision attribute (D). These two types of attributes are analogous to the independent variables and the dependent variable like in conventional regression analysis. The basic procedure in rough set analysis works through attribute reduction, i.e. finding a smaller set of attributes with the same or close classificatory power as the original set of attributes. On the basis of a reduced information table, decision rules are composed through determining the decision attributes value based on condition attributes values. A decision rule is presented in an "IF condition(s) THEN decision" format. The strength of decision rules is reflected in a measure named coverage.

Note that in various studies the prediction accuracy of decision rules was tested on the basis of new samples. This procedure has revealed rather satisfactory outcomes, witness an average prediction accuracy of around 75\% (see, for details, van Geenhuizen, 2008b; Soetanto and van Geenhuizen, 2007). 


\subsection{Variables and measurement}

Data were derived from face-to-face interviews with corporate managers and, additionally, from web presentation and annual reports of companies. The research design required the use of a semi-structured questionnaire in the interviews, to produce both scores in a standardised way and in-depth insights. Information from the semi-structured interviews was used to develop the information table, serving as a basis for a systematic analysis of the spatial layout of knowledge networks (Table 2).

Table 2 Structure of the information table (illustrated by three companies) a)

\begin{tabular}{|l|l|l|l|l|l|l|l|}
\hline $\begin{array}{l}\text { Objects } \\
\text { b) }\end{array}$ & $\mathbf{C}_{\mathbf{1}}$ & $\mathbf{C}_{\mathbf{2}}$ & $\mathbf{C}_{\mathbf{3}}$ & $\mathbf{C}_{\mathbf{4}}$ & $\mathbf{C}_{\mathbf{5}}$ & $\mathbf{C}_{\mathbf{6}}$ & $\begin{array}{l}\text { Decision } \\
\text { Attribute (D) }\end{array}$ \\
\hline & $\begin{array}{l}\text { Main } \\
\text { activity }\end{array}$ & $\begin{array}{l}\text { Length of } \\
\text { innovation } \\
\text { projects }\end{array}$ & $\begin{array}{l}\text { Spatial } \\
\text { focus in } \\
\text { strategy }\end{array}$ & Age & Size & Position & Spatial layout \\
\hline $\mathrm{O}_{1}$ & 3 & 2 & 4 & 2 & 2 & 1 & $1=$ Global \\
\hline $\mathrm{O}_{10}$ & 1 & 1 & 3 & 1 & 1 & $1 \mathrm{c})$ & $1=$ Global \\
\hline $\mathrm{O}_{14}$ & 1 & 1 & 1 & 2 & 1 & 1 & $2=$ Local/regional \\
\hline
\end{tabular}

a) $\mathrm{C}_{1}-\mathrm{C}_{6}$ : condition attributes. Classes of condition attributes: $\mathrm{C}_{1}$ (main activity/sector) (1) services, (2) research, (3) advanced manufacturing; $C_{2}$ (innovation project length): (1) weeks/some months, (2) a few years, (3) longer; $\mathrm{C}_{3}$ (general spatial focus in strategy) (1) local/regional, (2) local/regional and national, (3) local/regional and global, (4) global orientation; $\mathrm{C}_{4}$ (age): (1) 5 years and younger, (2) older than 5 years; $\mathrm{C}_{5}$ Size of company) (1) < 25, (2) 25-150, (3) >150 jobs; $\mathrm{C}_{6}$ (position connected with origin) (1) independent, (2) subsidiary, (3) academic spin-off, (4) corporate spin-off.

b) $\mathrm{O}_{1}-\mathrm{O}_{21}$ : case studies (companies).

c) acquired by an international firm one year after interview.

The two sets of attributes concerning strategic focus and internal capabilities were 'translated' into measurable characteristics as follows: main activity was measured on the basis of the categories services, research and specialized manufacturing; innovation intensity through the time-length (duration) of innovation projects, ranging from a substantial number of years (10-15 years) to a few weeks; and the spatial focus in the overall strategy through the focus in supplier- and customer markets, ranging from a strong local/regional focus to active globalization. In the frame of the current study, we were forced to use proxies in measuring internal capabilities, for example, age of company and company position (in terms of origin) in measuring experience. Size of the company is also included because some network capabilities may increase with size of young companies, particularly when staff capacity can be allocated to develop and elaborate network capability. 
Knowledge networks were measured as 'actual relations dealing with knowledge' in the frame of innovation, for example, concerning personal networks of the manager (CEO), customers, suppliers, knowledge institutes, alliance partners, head office if subsidiaries, etc. The knowledge relations identified covered small, focused teams as well as multiple focus networks, like the ones between some company staff and customers with multiple customer relations, all relatively stable in nature. ${ }^{1}$ The most important knowledge networks underpinning innovation were identified first and, next, the companies were classified as 'mainly local/regional' or 'mainly global' on the basis of dominance of either a local/regional or global layout. A two-class classification was adopted because a more refined classification would have rendered rough set analysis less useful.

In the interpretation of the rough set results the coverage of each rule was used. The coverage is an indicator of the strength of the rules, calculated as the number of cases with a similar set of attributes and score on the decision attribute as percentage share of all cases with this score on the decision attribute. The highest level reached in the analysis was $41.7 \%$ (5/12), but most rules did not exceed $22.2 \%$. In many other studies using rough set results, the highest coverage does not exceed 50\%. Another indicator used in our interpretation is the frequency in which particular condition attributes occur in the set of rules (Appendix 1). The higher the frequency, the stronger the explanatory power of the attribute is.

We measured the virtualization level of companies by using the relative frequency of interaction per electronic mode (relative to the maximum frequency), i.e. e-mail and telephone (including cellular) as rather conventional modes, and teleconferencing and videoconferencing as rather advanced modes not fully accepted today. For example, a frequency of use of 3 (class of 1 to 4 times per month), given a maximum of 5 , produces a virtualization level of $60 \%$. The overall virtualization score is the sum of the weighted individual scores. ${ }^{2}$ Virtualization of both management-oriented and innovation-oriented interactions was measured in this way. Problematic situations in management and innovation were measured using open questions. The answers were classified into four categories: (1) communication (C) referring to interpretation, feed-back, check, or depth of content, (2) management (M) referring to personal attention and related loyalty and cohesion, trust creation/maintenance, and management of interfaces, (3) regulation (R)

\footnotetext{
${ }^{1}$ Other ways of measuring, using e.g., joint co-authorship of scientific publications, patent applications or citations could have been selected. The sources involved have intrinsic advantages of being based on public information (not affected by sampling dangers in company surveys) and of reflecting certain benchmark levels of novelty. However, the connection with actual utilization of the new knowledge in business practices remains weak, and therefore, these measures were not used.

2 In order to articulate the difference in use between conventional electronic modes and rather advanced electronic modes, we assigned a weight of 2 to the last modes (1 to the first ones). This is of course arbitrary, but a slight change in weight does not produce different results.
} 
concerning access to domains etc. and ownership of data; responsibility and liability of co-developers, and protection and safety of data and procedures, and (4) network quality (N) like physical connectivity and capacity.

Further, to measure the strength and changes of local connectedness, importance attached to five different local networks by the company was used as a proxy. These networks were concerned with knowledge institutes, suppliers, customers, labour market relations and personal relationships of the entrepreneurs. Importance was measured through stated preference using a five-point scale.

\section{Shaping Factors and Support from Virtualization}

\subsection{Shape of networks and shaping factors}

The spatial layout of the knowledge networks of the sampled companies suggests a trend for co-existence, that is, particular segments of young innovative companies in urban areas employ mainly local/regional networks (8 case studies), while other segments employ mainly global networks (11 case studies). None of the companies were 'equally' local and global. The application of the rough set methodology has produced 12 decision rules referring to the above two classes of spatial layout, but the discussion in this section will be limited to eight decision rules that are solid in that they cover companies not subject to exceptional situations (such as the ICT crisis) (Table 3). Overall, no single condition attribute had an important classification power, it was often a combination of two conditions in the rules.

Considering the frequency of occurrence in the decision rules (Appendix 1), it appears that the following two condition attributes have a relatively strong power: position (in terms of origin and current corporate status) and spatial focus in the general strategy, these occur five and six times, respectively. The previous results point to organizational capability derived from the organization of origin (corporate or academic) and to the general spatial orientation (supplier- and customer markets) as determining factors. If we focus on mainly global knowledge networks, only position (in terms of origin) has a relatively strong power (Appendix 1).

A relatively strong decision rule is Rule 7 (Table 3), referring to mainly global networks. The rule is supported by five case studies (a coverage of $41.7 \%$ ) from different sectors, that is, biotechnology research and advanced optronics development and manufacturing. The rule says that relatively older companies engaged in (very) long-lasting innovation projects employ predominantly global knowledge networks. Apparently, companies that develop high levels of specialization in innovation after some years of existence (between 6 to 12 years) access the knowledge they need through global knowledge networks, like in 
co-creation and production with customers (e.g. designing specialized optical instruments) and in research of new medicines in collaboration with large pharmaceutical companies abroad.

Next in strength is Rule 5, equally referring to mainly global networks but with a lower coverage (25\%) and supported by three case studies. The decision rule is somewhat vague in stating that companies that are foreign subsidiary and have no specific spatial orientation in their overall strategy, employ predominantly global knowledge networks. The companies that support this rule are active in a range of ICT services (and engineering) in which the international orientation towards the mother company (in US, UK or France) is somewhat stronger than the local/regional orientation towards customers in Amsterdam and the Netherlands in shaping knowledge networks. Note that 'born globals' are also identified as a separate category (covered by Rule 8).

The decision rules referring to those companies mainly involved in local/regional knowledge networks, are different in that there is no strong rule and all rules have a coverage of $22 \%$, supported by two case studies. A local/regional orientation in the overall strategy is a relatively consistent condition, while other conditions feature just in single rules. With regard to main activity, most companies involved are service companies in ICT (like call centres, IT facility providers and system designers) and in biotechnology (routine and customized determination and testing). The manufacturing companies are relatively young and in early stages of product development and design, such as concerning new applications of sensor technology (optical monitoring) and laser technology (wafer cutting machines), for which the main network includes a range of organisations in the region and just a few abroad (university, public research institute, codeveloping companies). However, the last type of companies may easily become predominantly global in next stages of their development. 
Table 3 Rough set results concerning shaping factors of knowledge networks

\begin{tabular}{|c|c|}
\hline Conditions in rules & $\begin{array}{l}\text { Rules, number of cases and coverage (\%); specific } \\
\text { conditions (in italic) }\end{array}$ \\
\hline \multicolumn{2}{|l|}{ Local/regional } \\
\hline $\begin{array}{l}\text { Size - spatial focus in } \\
\text { overall strategy }\end{array}$ & $\begin{array}{l}\text { Rule 1: } 2(22.2 \%) \text {; medium-sized or larger and an overall } \\
\text { strategy with a strong local/regional orientation. ICT services, } \\
\text { like specialized call centres and facility providers. }\end{array}$ \\
\hline $\begin{array}{l}\text { Position - spatial focus } \\
\text { in overall strategy }\end{array}$ & $\begin{array}{l}\text { Rule 2: } 2 \text { (22.2\%); independent position and an overall } \\
\text { strategy with a strong local/regional orientation. Services in } \\
\text { biotechnology (standard). }\end{array}$ \\
\hline $\begin{array}{l}\text { Position - duration of } \\
\text { innovation projects }\end{array}$ & $\begin{array}{l}\text { Rule 3: } 2 \text { (22.2\%); academic spin-off and short innovation } \\
\text { projects. ICT services for non-standard problem-solving and } \\
\text { optimisation. }\end{array}$ \\
\hline $\begin{array}{l}\text { Age - main activity - } \\
\text { spatial focus in overall } \\
\text { strategy }\end{array}$ & $\begin{array}{l}\text { Rule 4: } 2 \text { (22.2\%); young, manufacturing companies without a } \\
\text { spatial focus in the overall strategy. Advanced optronics } \\
\text { companies in (re)start (e.g. monitoring systems). }\end{array}$ \\
\hline \multicolumn{2}{|l|}{ Global } \\
\hline $\begin{array}{l}\text { Position - spatial focus } \\
\text { in overall strategy }\end{array}$ & $\begin{array}{l}\text { Rule 5: } 3(25.0 \%) \text {; foreign subsidiaries, without a spatial focus } \\
\text { in the overall strategy. ICT services (interface development } \\
\text { and platform architecture) and engineering services. }\end{array}$ \\
\hline \begin{tabular}{lll|}
$\begin{array}{l}\text { Position } \\
\text { activity }\end{array}$ & - & main \\
\end{tabular} & $\begin{array}{l}\text { Rule 6: } 1 \text { (8.3\%); corporate spin-off and engaged in services. } \\
\text { Advanced biotechnology services (non-standard process } \\
\text { optimisation) in a global network gained from parent } \\
\text { company. }\end{array}$ \\
\hline $\begin{array}{l}\text { Age - duration of } \\
\text { innovation projects }\end{array}$ & $\begin{array}{l}\text { Rule 7: } 5 \text { (41.7\%); older age and (very) long lasting } \\
\text { innovation projects. Biotechnology (medical) research and } \\
\text { advanced optronics development (e.g. video monitoring and } \\
\text { electron microscopes). }\end{array}$ \\
\hline $\begin{array}{l}\text { Age - spatial focus in } \\
\text { overall strategy }\end{array}$ & $\begin{array}{l}\text { Rule 8: } 2 \text { (16.7\%); young age and global orientation ('born } \\
\text { global'). Biotechnology (medical) research (foreign } \\
\text { subsidiary) and ICT services (design of digital protection } \\
\text { software). }\end{array}$ \\
\hline
\end{tabular}

Source: Adapted from van Geenhuizen (2008b)

\subsection{Virtualization support for global companies}

Next, we move to support from virtualization for those companies that were classified as global in knowledge networking (Table 4). We observe the following overall trend, i.e. an 
almost systematically higher level of virtualization in management-oriented interaction (M) compared with innovation-oriented interaction (I), with average scores of 350 and 305, respectively. In addition, relatively strongly virtualized companies (with scores of 540 and 440) make often use of teleconferencing (one to four times a week) as far as management is concerned. Videoconferencing is less popular, witness a highest frequency of one to four times per month. In more detail, the globalized companies (11 case studies) show the following trends of differntiation(Table 4):

- In the category 'older age and long lasting innovation' (Rule 7) as shaping factors of global knowledge networks, there is a clear difference between the engineeringoriented companies (instruments for detection and advanced microscopes) and the science-based companies (biotechnology - new drugs). The first have a much higher level of adoption of ICT than the last ones (a score of 410 versus 230) and are also involved in using advanced tools in innovation practices.

- There is a clear difference within biotechnology, between research firms (Rule 7) and services firms (Rule 6); although both types employ global networks, the last type shows relatively high levels of ICT use including advanced ICT tools in cotesting with customers (440 versus 230 on average for research companies).

- A different behaviour is also shown among ICT services companies. The ones active in telecommunication themselves (Rule 5 and Rule 8) show a relatively high level of ICT use, compared to the ones active in other types of ICT services (Rule 5) (395 versus 280).

Problematic issues perceived in virtualization are concerned with limitations in communication (C). Almost all companies perceive such problems, these mainly concern trust building and trust refreshing, lack of in-depth communication, lack of easy check of truth, and problematic understanding. Management problems (M) and networks issues (N) are mentioned less often. Regulation issues (R) emerge when virtualization is concerned with interaction in innovation practices. These issues mainly refer to liability (responsibility) and protection (safety) between collaboration partners and with the external world.

Overall, the results indicate relatively high levels of telecommunication and advanced ICT tools use among 1) optronics instruments industry, 2) advanced biotechnology services, and 3) ICT services involved in telecommunication. Accordingly, the results may confirm a strong influence of the sector on virtualization, both in terms of familiarity with electronics and telecommunication (e.g. Sapsed, et al., 2005) and in terms of type of knowledge-base and learning used (Asheim et al., 2007). Indeed, optronics research and learning tend to benefit stronger from virtualization due to the importance of applied, problem-related engineering knowledge and need for open and interactive learning with customers; this in contrast with biotechnology drugs research as being largely based on documentation in patents and publications, and formal research collaboration with 
research institutes and research companies/departments. Advanced services, including close interaction with customers abroad (both in biotechnology and ICT) also tend to take stronger advantage of opportunities of virtualization.

Table 4 Virtualization scores of globally oriented companies

\begin{tabular}{|c|c|c|c|c|}
\hline $\begin{array}{l}\text { Companies } \\
\text { (objects) }\end{array}$ & $\mathbf{M}$ a) & I a) & $\begin{array}{l}\text { Highest frequency score on two } \\
\text { communication modes b); advanced ICT tool } \\
\text { use in innovation (italic) }\end{array}$ & $\begin{array}{l}\text { Problems } \\
\text { faced by } \\
\text { company }\end{array}$ \\
\hline $\begin{array}{l}\text { Rule } 7 \\
\mathrm{O}_{1 \text { optronics }}\end{array}$ & 400 & 380 & $\begin{array}{l}\text {-teleconference and videoconference: } 1-4 \mathrm{x} \text { per } \\
\text { month (M); from sequential to simultaneous } \\
\text { virtual design with customers }\end{array}$ & C, $Q$ \\
\hline $\mathrm{O}_{2}$ optronics & 540 & 320 & $\begin{array}{l}\text {-teleconference: } 1-4 \mathrm{x} \text { per week (M); remote } \\
\text { control of equipment at customers' place }\end{array}$ & $\mathrm{C}, \mathrm{M}, \mathrm{N}, \mathrm{R}$ \\
\hline $\mathrm{O}_{3}$ biotech research & 240 & 240 & -teleconference: 1-4x per month (M and I); none & $\mathrm{C}$ \\
\hline $\mathrm{O}_{4}$ biotech research & 220 & 220 & -teleconference: 3-6x per year (M and I); none & $\mathrm{C}$ \\
\hline $\mathrm{O}_{5 \text { biotech research }}$ & 240 & 220 & -teleconference: 1 -4x per month $(\mathrm{M})$; none & $\mathrm{C}$ \\
\hline $\begin{array}{l}\text { Rule } 5 \\
\mathrm{O}_{6 \text { telecommunication }} \\
\mathrm{O}_{7 \text { ICT }}\end{array}$ & $\begin{array}{l}440 \\
260\end{array}$ & $\begin{array}{l}440 \\
240\end{array}$ & $\begin{array}{l}\text {-teleconference: } 1-4 \mathrm{x} \text { per week (M and I); none } \\
\text {-teleconference: } 1-4 \mathrm{x} \text { per week (I); grid- } \\
\text { computing d) }\end{array}$ & C \\
\hline $\mathrm{O}_{8}$ ICT/engineering & 320 & 300 & $\begin{array}{l}\text {-videoconference: } 1-4 \mathrm{x} \text { per month (M and I); } \\
\text { none }\end{array}$ & -- \\
\hline $\begin{array}{l}\text { Rule } 8 \\
\mathrm{O}_{9} \text { biotech research }\end{array}$ & 380 & 220 & $\begin{array}{l}\text {-teleconference: } 1-4 x \text { per month }(\mathrm{M}) \text {; } \\
\text { data-mining }\end{array}$ & $\mathrm{C}$ \\
\hline $\mathrm{O}_{10 \text { telecommunication }}$ & 360 & 340 & -teleconference: 1-4x per week (M); none & $\mathrm{C}, \mathrm{M}$ \\
\hline $\begin{array}{l}\text { Rule } 6 \\
\mathrm{O}_{11} \text { advanced biotech } \\
\text { services }\end{array}$ & 440 & 440 & $\begin{array}{l}\text {-teleconference: } 1-4 \mathrm{x} \text { per week ( } \mathrm{M} \text { and } \mathrm{I}) \text {; } \\
\text { remote control (co-control) in experiments }\end{array}$ & $\mathrm{C}, \mathrm{R}$ \\
\hline
\end{tabular}

a) M: management-oriented; I: innovation-oriented; theoretical maximum of scores: 600 .

b) Teleconference and videoconference

c) $\mathrm{C}=$ communication issues; $\mathrm{M}=$ management issues; $\mathrm{R}=$ regulation issues; $\mathrm{N}=$ network issues; $\mathrm{Q}=$ question mark on advantages of virtualization.

d) Relatively simple services (programming and customer services) are outsourced to India. 
Remarkably, the overall picture suggests relatively low levels of virtualization in innovation processes. The latter may be due to importance of organizational adjustments without which the new technology (virtual simulation and experimentation) cannot be properly introduced, as well as to regulatory issues that are not yet solved.

\section{Weakening or Strengthening of Local Connectedness}

Our understanding of the extent to which globalization in knowledge relations decreases local connectedness is rather limited to date. However, insights are quickly increasing, particularly concerning the influence of global knowledge on local knowledge diffusion, and the role of 'gatekeepers' in this diffusion. In our analysis we have however, taken a broader approach, namely the relation with weakening/strengthening of a set of local relations (not merely knowledge). To reveal the above potential impacts, we first discuss a comparison between companies with local/regional knowledge networks and companies engaged in global knowledge networks on current strength of local connectedness and changes herein.

Companies mainly employing global networks tend to be systematically less strongly connected with local knowledge institutes, other companies (suppliers and customers), labour market and personal networks (Table 5). This holds for the current situation (an average difference of -0.6) but also - and somewhat stronger - for changes today/near future (an average difference of -0.8). Supplier relations are facing the largest difference between the two categories of companies in the current situation (-1.0), whereas knowledge institute relations and personal relations (entrepreneurs) are facing the largest difference for today/near future (-1.1 and -1.3, respectively). The outcomes of the F-test however reveal only substantial differences in supplier relations in both current and most recent/near future situations, particularly concerning the last one. In addition, the difference in personal relations is substantial only for the changing situation today/close future.

Taken from a another perspective, namely differences over time for companies with predominantly local knowledge networks and for those with a predominantly global knowledge network, Table 5 reveals a general trend for strengthening local networks. However, the first tend to strengthen all local networks today, particularly labour relations (from 3.6 to 4.5), whereas the last tend to reinforce only local customer relations (from 2.7 to 3.6) and to a smaller extent local labour relations (from 3.4 to 3.7). 
Table 5 Local companies (1) versus global companies (2) on strength of local relations (scores) (a)

\begin{tabular}{|l|c|c|l|l|}
\hline Local relations & $\begin{array}{l}\text { Scores by local } \\
\text { companies (1) }\end{array}$ & $\begin{array}{l}\text { Scores by global } \\
\text { companies (2) }\end{array}$ & $\begin{array}{l}\text { Difference } \\
\text { (2) and (1) }\end{array}$ & F - test (b) \\
\hline \multicolumn{1}{|c|}{ Current situation } & & & & \\
\hline Knowledge relations & 3.8 & 3.3 & -0.5 & 0.954 \\
\hline Supplier relations & 2.9 & 1.9 & -1.0 & $4.236^{*}$ \\
\hline Customer relations & 3.3 & 2.7 & -0.6 & 1.123 \\
\hline Labour relations & 3.6 & 3.4 & -0.2 & 0.089 \\
\hline Personal relations & 3.7 & 3.0 & -0.7 & 2.171 \\
\hline Average & & & -0.6 & \\
\hline \multicolumn{1}{|c|}{ Changed situation } & & 3.3 & & \\
\hline Knowledge relations & 4.4 & 1.5 & -1.1 & 0.189 \\
\hline Supplier relations & 3.1 & 3.6 & -0.6 & $0.012^{* *}$ \\
\hline Customer relations & 3.8 & 3.7 & -0.6 & 0.811 \\
\hline Labour relations & 4.5 & 3.0 & -1.3 & 0.520 \\
\hline Personal relations & 4.3 & & -0.8 & $0.099 *$ \\
\hline Average & & &
\end{tabular}

a) based on stated preference for utilization of a set of five local relations using a five-point scale.

b) one-way ANOVA test; p-values: * 0.10 confidence level; ** 0.05 confidence level; Welch and Forsythe \& Brown tests produce similar results.

$\mathrm{N}$ (companies) $=21$

Source: Adapted from van Geenhuizen (2008b).

Table 6 shows trends in local connectedness among global companies as follows:

- In the category 'older age and long lasting innovation projects' companies are clearly different (from $-21 \%$ to $+16 \%$ change), ranging from decreasing importance if building global co-creation and customer relations, to increasing importance if remaining interacting with the local university (as academic spinoffs). The last holds also for 'corporate spin-offs' and the local company of origin.

- In the category 'foreign subsidiaries and indifferent spatial focus in overall strategy' companies face a situation of already established local/regional customers or high importance of building such a customer base (from no change to $+16 \%$ change).

- In the category 'born global', companies are different dependent on recent adoption of the role of knowledge partner of an MNC abroad (-33\%).

- Acquisition/expansion of foreign MNCs tends to have a substantial influence, but in different directions. If their subsidiaries aim to increase market size, they tend to strongly rely on local relations. If subsidiaries, however, adopt the role of important learning partner they tend to face a weakening of these relations. 
- An increase of local connectedness and strong virtualization support may go handin-hand in specific situations, namely in which despite advanced global co-creation and co-testing the companies maintain important relations with the local university/company of origin (two case studies).

Table 6 Changes in local connectedness scores of globally oriented companies

\begin{tabular}{|c|c|c|}
\hline $\begin{array}{l}\text { Companies } \\
\text { (objects) }\end{array}$ & $\begin{array}{l}\text { Change } \\
\text { (a) }\end{array}$ & Additional information \\
\hline Rule 7 & & \\
\hline $\mathrm{O}_{1 \text { optronics }}$ & $-21 \%$ & Increasing global sourcing (knowledge and components) \\
\hline $\mathrm{O}_{2}$ optronics & $+6 \%$ & $\begin{array}{l}\text { Increasing establishment of local customer relations } \\
\text { (subsidiary of MNC) and a remaining strong relation with } \\
\text { local knowledge company; strong support from virtualization } \\
\text { in co-creation with customers abroad }\end{array}$ \\
\hline $\mathrm{O}_{3}$ biotech research & $0 \%$ & No changes \\
\hline $\mathrm{O}_{4}$ biotech research & $+16 \%$ & $\begin{array}{l}\text { Reinforcing of relations with local knowledge institute (as } \\
\text { university spin-off) and biotech companies }\end{array}$ \\
\hline $\mathrm{O}_{5 \text { biotech research }}$ & $-17 \%$ & $\begin{array}{l}\text { Decreasing importance of local labour market relations and } \\
\text { personal relations }\end{array}$ \\
\hline $\begin{array}{l}\text { Rule } 5 \\
\mathrm{O}_{6} \\
\text { telecommunication }\end{array}$ & $0 \%$ & No changes (subsidiary of UK MNC) \\
\hline $\mathrm{O}_{7 \text { ICT services }}$ & $+16 \%$ & $\begin{array}{l}\text { Reinforcing of local relations with customers, labour market } \\
\text { and personal network (subsidiary of US MNC) }\end{array}$ \\
\hline $\mathrm{O}_{8}$ ICT/engineering & $0 \%$ & $\begin{array}{l}\text { Reinforcing of local relations with customers (subsidiary of } \\
\text { small French MNC) but weakening of knowledge relations }\end{array}$ \\
\hline Rule 8 & & \\
\hline $\mathrm{O}_{9}$ biotech research & $-33 \%$ & $\begin{array}{l}\text { Weakening of all relations due to adoption of model of } \\
\text { 'reverse' knowledge transfer (in Danish MNC) }\end{array}$ \\
\hline $\begin{array}{l}\mathrm{O}_{10} \\
\text { telecommunication }\end{array}$ & $0 \%$ & $\begin{array}{l}\text { Strengthening of local customer relations but weakening of } \\
\text { personal relations }\end{array}$ \\
\hline $\begin{array}{l}\text { Rule } 6 \\
\mathrm{O}_{11 \text { advanced biotech }} \\
\text { services }\end{array}$ & $+15 \%$ & $\begin{array}{l}\text { Reinforcing of local knowledge relations and customer } \\
\text { relations; strong virtualization support in co-testing with } \\
\text { customers abroad }\end{array}$ \\
\hline
\end{tabular}


a) Change in summed scores on five location factors (knowledge institutes, suppliers, customers, labour market and personal relations).

The previous findings suggest that a weakening of local networks among globally oriented companies is not all-important. Global sourcing and co-creation and being involved as a global knowledge source in open innovation (MNC network) tend to urge companies to reduce local connectedness. However, specific local knowledge relationships and a corporate mission of local/regional customer market development tend to act as important counterforces.

\section{Concluding Remarks}

The contribution of the present study to the literature is an in-depth analysis of globally shaped knowledge networks and virtualization among young high-tech companies, particularly the connection between global learning and changes in local connectedness. By adopting an entrepreneurial perspective, the study has attempted to identify relevant strategies, capabilities and virtualization factors, aside from the influence of multinational corporations (MNCs) on knowledge networks. The results, drawn from a selected sample of 21 urban high-technology companies in the Netherlands, suggested a coexistence of predominantly local/regional and global knowledge networks, the former mainly shaped by a regional focus in the overall strategy and the latter by older age and long-term innovation projects, network capabilities derived from parent companies, or strategy within MNCs' networks. Knowledge networking abroad tended to be partially supported by virtualization. Differences in this support occur between economic sectors, dependent on familiarity with ICT and electronic tools, and dependent on type of learning (sciencebased versus engineering-based). Thus, virtualization tends to be relatively modest in biotechnology drugs research but relatively strong in advanced biotechnology services (co-testing), optronics instrument manufacturing, and advanced telecommunication services. Overall, different from what the literature suggests, the level of virtualization tended to be low, particularly in innovation practices. This situation matches with the findings concerning the concomitant need for important organizational adjustments in companies, as well as regulatory adjustments. Also, virtualization tended to have no straightforward relation with changes in local connectedness. In some cases, local connectedness may have decreased among others under the influence of virtualization, but in other cases the reversed happened: due to remaining relations with the local university/company of origin, local connectedness increased despite strong support from virtualization in global innovation practices.

In general, there was a loss of local connectedness among independent companies sourcing or co-creating global knowledge as well as subsidiaries engaged in 'reverse' 
knowledge transfer in MNC organisations. The same tended to be true for 'born globals'. We could however also identify counteracting forces, connected with the origin of the companies as local spin-offs and with a corporate (MNC) mission of subsidiaries in extending local/regional customer markets. Overall, delocalizing of networks and weakening of clusters or urban production systems are not pre-dominating and developments seem rather differentiated within urban regions. The latter situation is important to be taken into account by policymakers if policies are aimed at strengthening collaboration between companies and knowledge institutes within a regional context. The differentiation in global knowledge relations among young high-tech companies ranges from no substantial global relations to global sourcing/co-creation and 'reverse' transfer relations with MNCs.

This study has limitations following from choices in its design. The observed trends only refer to relatively young companies. Among older ones, the trend of loss of local connectedness may be stronger, particularly if these companies have reached a 'ceiling' in support from virtualization and move research or production activity abroad. Here is an interesting path for future research. Given the method used and differentiating factors forwarded, another path for future research is a solid statistical investigation of the differentiation between young high-tech companies in various cities/regions.

\section{Acknowledgement}

This study has benefited from funding by the Netherlands Organisation for Scientific Research (project number 014-43-616-P), Delft Centre of Sustainable Urban Areas (Delft University of Technology, The Netherlands), and by NICIS Institute.

\section{References}

Ambos, T.C., Ambos, B. and Schlegelmilch, B.B., 2006, Learning from foreign subsidiaries: an empirical investigation of headquarters' benefits from reverse knowledge transfers. International Business Review 15 (3): 294-312.

Amighini, A. and Rabellotti, R., 2006. The effects of globalization on Italian industrial districts: Evidence from the footwear sector. European Planning Studies, 14 (4): 485-502.

Andersson, S. and Wictor, I. 2003, Innovative Internationalisation in New Firms: Born Globals - the Swedish Case, Journal of International Entrepreneurship, 1: 249-276.

Asheim B., Coenen, L., and Vang, J., 2007, Face-to-face, buzz, and knowledge bases: sociospatial implications for learning, innovation, and innovation policy. Environment \& Planning C: Government and Policy, 25: 655-670.

Ayres, R.U., and Williams, E., 2004, The digital economy: where do we stand? Technological Forecasting and Social Change 71 (4): 315-339.

Badrinarayanan, V. and Arnett, D.B., 2008, Effective virtual new product development teams: an integrated framework, Journal of Business \& Industrial Marketing, 23 (4): 242-248.

Barney, J.B., 1991, Firm resources and sustained competitive advantage, Journal of Management, 17 (10: 99-120. 
Barney, J.B. and, Clark, D.N., 2007, Resource-based theory: Creating sustaining competitive advantage, NY: Oxford University.

Bathelt, H., Malmberg, A. and Maskell, P., 2004, Clusters and knowledge: local buzz, global pipelines and the process of knowledge creation, Progress in Human Geography, 28: 31-56.

Becker, M.C., Salvatore, P., and Zirpoli, F., 2005, The impact of virtual simulation tools on problem-solving and new product development organization, Research Policy, 34: 1305-1321.

Bell, B. S. and Kozlowski, S. W. J. 2002. A typology of virtual teams. Group \& Organization Management, 27: 14 - 49.

Best, M., 2001, The New Competitive Advantage, Oxford: Oxford University Press.

Bolisani, E. and Scarso, E., 2011, Knowledge Codifications and ICT Use in Business Networks, Encyclopedia of Knowledge Management 2011: 506-514.

Borgatti, S.P and P. Foster, 2003, The network paradigm in organizational research. A review and typology, Journal of Management, 29: 991-1013.

Boschma, R. A.. 2005, Proximity and innovation: A critical assessment, Regional Studies, 39 (1): 61-74.

Britton, J.N.H. 2004. High technology localization and extra-regional networks, Entrepreneurship \& Regional Development, 16: 369-390.

Brush, C.G., Greene, P.G., Hart, M.M. and H.S. Haller, 2001, From initial idea to unique advantage; the entrepreneurial challenge to construct a resource base, Academy of Management Executive, 15: 64-78.

Bunnell, T.G. and Coe, N.M., 2001, Spaces and scales of innovation, Progress in Human Geography, 25 (4): 569-589.

Chesbrough, H., Vanhaverbeke, W., West, J. (Eds), 2006, Open Innovation: Researching a New Paradigm. Oxford: Oxford University Press.

Chetty, S. and Wilson, H.I.M., 2003, Collaborating with competitors to acquire resources, International Business Review, 12: 61-81.

Chudoba, K. M., Wynn, E., Lu, M. and Watson-Manheim, M. B. 2005, How virtual are we? Measuring virtuality and understanding its impact in a global organization. Info Systems Journal, 15: 279-306.

Coenen, L., J. Moodysson and Asheim, B., 2004 Nodes, Networks and Proximities: On the Knowledge Dynamics of the Medicon Valley Biotech Cluster, European Planning Studies, 12 (7): 1003-1018.

Cohen, W. and Levinthal, D., 1990, Absorptive capacity: a new perspective on learning and innovation, Administrative Science Quarterly, 35: 128-152.

Cramton, C. and Orvis, K., 2003, Overcoming Barriers in Information Sharing in Virtual Teams. In: Virtual Teams That Work, Gibson, C. \& Cohen, S. (eds), pp. 214-229. Jossey-Bass, San Francisco, CA, USA.

Cumbers, A., Mackinnon, D. and Chapman, K., 2003, Innovation, collaboration, and learning in regional clusters: a study of SMEs in the Aberdeen oil complex, Environment and Planning A, 35: 1689-1706.

Dahlander, L. and Gann, D.M., 2010, How open is innovation? Research Policy, 39 (6): 699-709.

Dana, L.P., 2001, Introduction networks, internationalization and policy, Small Business Economics, 16: 5762.

DeMartino, R., McHardy Reid, D. and Zygliodopolous, S. C., 2006, Balancing localization and globalization: exploring the impact of firm internationalization on a regional cluster, Entrepreneurship \& Regional Development, 18: 1-24.

Dicken, P., 2004, Global Shift: Reshaping the Global Economic Map in the $21^{\text {st }}$ Century, London: Sage Publications.

Dunning, J.H., 2000, The eclectic paradigm as an envelope for economic and business theories of MNE activity, International Business Review, 9 (2) 163-190.

Ebrahim, N.A., Ahmed, S., Taha, Z., 2009, Virtual R\&D teams on small and medium-sized enterprises, Scientific Research and Essays, 4 (13): 1575-1590.

Forsgren, M., 2002, The concept of learning in Uppsala internationalization process model: a critical review. International Business Review 11: 257-277.

Frost, T.S., 2001, The geographic sources of foreign subsidiaries' innovations, Strategic Management Journal, 22: 101-123. 
Frost, T.S. and Zhou, C., 2005, R\&D co-practice and 'reverse' knowledge integration in multinational firms. Journal of International Business Studies, 36: 676-687.

Geenhuizen, M. van, 2006, ICT, Location Dynamics and the Future of Cities, Delft/The Hague: Delft University of Technology, Faculty of Technology, Policy and Management/Netherlands Science Foundation (www.nwo.nl/nwohome.nsf).

Geenhuizen, M. van, and Nijkamp, P., 2007, Cities and Footlooseness: In Search of Place-bound Companies and Effective Location, Environment \& Planning C, Government and Policy, 25 (5): 692-708.

Geenhuizen, M. van, 2008a, Knowledge networks of young innovators in the urban economy; biotechnology as a case study, Entrepreneurship and Regional Development 20 (2): 161-183.

Geenhuizen, M. van, 2008b, Modelling dynamics of knowledge networks and local connectedness: a case study of urban high-tech companies in The Netherlands, Annals of Regional Science, 41: 813-833.

Gertler, M., 2003, Tacit knowledge and the economic geography of context, or The undefinable tacitness of being (there), Journal of Economic Geography, 3: 75-99.

Gertler, M. and Levitte, Y.M., 2005, Local Nodes in Global Networks: The Geography of Knowledge Flows in Biotechnology Innovation, Industry and Innovation, 12 (4): 487-507.

Gibson, C. B. and Cohen, S. G. (eds.), 2003, Virtual Teams that Work. Jossey-Bass, A Willey Imprint. San Fransisco.

Graf, H. and Krüger, J.J., 2011, The Performance of Gatekeepers in Innovator Networks, Industry and Innovation, 18(1): 69-88.

Grant, R.M., 1996, Toward a knowledge-based theory of the firm. Strategic Management Journal, 17: 109122.

Guiliani, E. and Bell, M., 2005, The micro-determinants of meso-level learning and innovation: evidence from a Chilean wine cluster, Research Policy 34 (1): 47-68.

Hendry, C. and Brown, J., 2006. Dynamics of Clustering and Performance in the UK Opto-electronics Industry, Regional Studies, 40: 707-725.

Hinds, P. and Kiesler, S. (eds.) 2002, Distributed Work. The MIT Press, Cambridge. Massachusetts.

Hoang, H. and Antoncic, B. 2003, Network-based research in entrepreneurship: a critical review, Journal of Business Venturing, 17: 1-23.

Jarvenpaa, S., Knoll, K.and Leidner, D., 1998, Is anybody out there? Antecedents of trust in global virtual teams. Journal of Management Information Systems, 14: 29-64.

Johanson, J. and Vahlne, J.E., 1977. The internationalization process of the firm - A model of knowledge development and increasing foreign market commitments. Journal of International Business Studies 8 (1): 23-32.

Johnson, D.K.N., Siripong, N., and Brown, A.S., 2006, The Demise of Distance? The Declining Role of Physical Proximity for Knowledge Transmission, Growth and Change, 37 (1): 19-33.

Jones, M., Dimitratos, P., Fletcher, M., Young, S., (eds) 2009, Internationalization, entrepreneurship and the smaller firm. Evidence from around the world. Cheltenham: Edward Elgar.

Jong, J. P. J. D. and Freel, M., 2010, Absorptive capacity and the reach of collaboration in high technology small firms. Research Policy 39: 47-54.

Jong, R. de, Schalk, R., Curşeu, P. L., 2008, Virtual communicating, conflicts and performance in teams, Team Performance Management, 14 (7/8): 364-380.

Joshi, A., Lazarova, M., Liao, H., 2009, Getting everyone on board: the role of inspirational leadership in geographically dispersed teams. Organization Science, 20 (1): 240-252.

Kafouros, M., Buckley, P. Sharp, J., Wang, C., 2008, The role of internationalization in explaining innovation behaviour. Technovation 28: 63-74.

Klopotek, M.A. and Wierzchon, S.T., 2009, A New Qualitative Rough-Set Approach to Modelling Belief Function. Rough Sets and Current Trends in Computing. Berlin/Heidelberg: Springer.

Laursen, K. and Salter, A.J., 2006, Open innovation: the role of openness in explaining innovation performance among UK manufacturing firms, Strategic Management Journal, 27: 131-150. 
Lawton-Smith, H., 2004, The Biotechnology Industry in Oxfordshire: Enterprise and Innovation, European Planning Studies, 12: 986-1001.

Lechner, C. and Dowling, M., 2003, Firm networks: external relationships as sources for the growth and competitiveness of entrepreneurial firms. Entrepreneurship \& Regional Development, 15: 1-26.

Lichtenthaler U. and Lichtenthaler, E., 2009, A Capability-Based Framework for Open Innovation: Complementary Absorptive Capacity. Journal of Management Studies 46 (8) 1315-1338.

Lipnack, J. and Stamps, J. 1997, Virtual Teams: Reaching Across Space, Time, and Organization with Technology. John Wiley \& Sons, Inc. New York.

Lockett, A. and Thompson, S., 2001, Resource-based view and economics, Journal of Management, 27: 723-755.

Madsen, T-K. and Servais, P., 1997, The Internationalisation of Born Globals: An Evolutionary Process? International Business Review, 6 (6): 561-583.

Manguematin, V., Lemarie, S., Boissin, J.P., Catherine, D., Corolleur, F., Cororini, R and Trommeter, M., 2003, Development of SMEs and heterogeneity of trajectories: the case of biotechnology in France, Research Policy, 32: 621-638.

Martins, L.L., Gilson, L.L. and Travis Maynard, M., 2004, Virtual Teams: What Do We know and Where Do We Go From Here? Journal of Management, 30 (6): 805-835.

Martin, R. and Sunley, P., 2002, Deconstructing clusters, Journal of Economic Geography, 3: 1-15.

Maznovsky, M.L and Chudoba, K.M., 2000, Bridging Space over Time: Global Virtual Team Dynamics and Effectiveness, Organization Science 11 (5): 473-492.

McDougall, P., Shane, S., and Oviatt, B.M. 1994, Explaining the Formation of International New Ventures, Journal of Business Venturing, 9: 469-487.

McKelvey, M., Alm, H. and Riccaboni, M., 2004, Does location matter? Knowledge collaboration in the Swedish biotechnology-pharmaceutical sector. Working paper ESSY (Gothenburg: Chalmers University).

Morrison, A., Rabellotti, R., and Zirulia, L. 2011, When do global pipelines enhance knowledge diffusion in clusters? Papers in Evolutionary Economic Geography, Utrecht: Utrecht University.

Mytelka, L., 2004, Clustering, long-distance partnership and the SME: a study of the French biotechnology sector. Int Journal of Technology Management, 27 (8): 791-808.

Nooteboom, B. 2000, Learning and innovation in organisations and economies. Oxford: Oxford University Press.

Pawlak, Z., 1991, Rough Sets. Dordrecht: Kluwer.

Pawlak Z., 2001, AI and Intelligent Industrial Application: The Rough Set Perspective, Cybernetics and Systems: An International Journal, 31: 227-252.

Pazos, P. and Beruvides, M. G., 2011, Performance patterns in face-to-face and computer-supported teams, Team Performance Management, 17 (1/2): 83-101.

Polkowski, L. and Skowron, A., 1998 (eds) Rough Set in Knowledge Discovery. Berlin: Springer, Physica Verlag.

Porter, M.E., 2000, Locations, clusters, and company strategy, Clark, G.L., Feldman, M. and Gertler, M. The Oxford Handbook of Economic Geography, Oxford: Oxford University Press, pp. 253-274.

Potter, R.E and Balthazard, P.A., 2002, Virtual Team Interaction Styles: Assessment and Effects. Int. Journal of Human-Computer Studies. 56: 423 - 443.

Rialp, A, Rialp, J., and Knight, G.A., 2005, The Phenomenon of Early Internationalizing Firms: What Do We Know After a Decade (1993-2003) of Scientific Inquiry? International Business Review, 14 (2): 147-166.

Roijakkers, N. and Hagedoorn, J., 2006, Inter-firm R\&D partnering in pharmaceutical biotechnology since 1975: Trends, patterns, and networks, Research Policy, 32: 431-446.

Sapsed, J., Gann, D., Marshall, D., Salter, A., 2005, From Here to Eternity? The Practice of Knowledge Transfer in Dispersed and Co-located Project Organizations. European Planning Studies, 13 (6): 831851. 
Schunn, C. D., Crowley, K., and Okada, T., 2002, What Makes Collaborations Across a Distance Succeed? The Case of the Cognitive Science Community. In Hinds, P and Kiesler, S (ed). 2002. Distributed Work. The MIT Press Cambridge, Massachusetts.

Simmie, J., 2003, Innovation and Urban Regions as National and International Nodes for the Transfer and Sharing of Knowledge, Regional Studies, 37: 607-620.

Solomon, C. M., 2001, Managing Virtual Teams. Workforce, 80: 60-64.

Soetanto, D. P., Geenhuizen, M. van, 2007, Technology Incubators and Knowledge Networks. A Rough Set Approach in Comparative Project Analysis, Environment \& Planning B, Planning \& Design, 34: 1011-1029.

Stonehouse, G., Campbell, D., Hamill, J., and Purdie, T., 2004, Global and Transnational Business: Strategy and Management. John Wiley \& Sons, Ltd. Sussex, England.

Storper, M., and Scott, A.J., 2009, Rethinking human capital, creativity and urban growth. Journal of Economic Geography, 9: 147-167.

Taheri, M. and van Geenhuizen, M., 2011, How human capital and social networks may influence patterns of learning among academic spin-offs. Papers in Regional Science (in print).

Teece, D.J., 2009, Dynamic capabilities and strategic management; organizing for innovation and growth, New York: Oxford University Press.

Tidd, J., Bessant, J., Pavitt, K., 2005, Managing innovation, integrating technological, market and organizational change, Chicester: Wiley.

The Economist, 2011, Clusters flustered. Global competition seems to be weakening the benefits of being in a cluster, April $14^{\text {th }} 2011$.

Torre, A., 2008, On the role played by temporary geographical proximity on knowledge transmission, Regional Studies, 42 (6): 869-889.

Vaccaro, A., Veloso F., Brusoni S., 2009, The Impact of Virtual Technologies on Knowledge-Based Processes: An Empirical Study, Research Policy 38 (8): 1278-1287.

Vaccaro, A., Veloso, F., Parente R., 2010, Virtual Knowledge Management, Innovation Capabilities, and Firm Performance, Technological Forecasting and Social Change 77(7): 1076-1089.

Vrande, V.J.A. van der, Jong, J.P.J. de, Vanhaverbeke, W. and Rochemont, M. de, 2008, Open innovation in SME's: trends, motives and management challenges, Technovation, 29: 423-437.

Wolfe, D. and Gertler, M., 2004, Clusters from the inside out: local dynamics and global linkages, Urban Studies, 41 (5/6): 1071-1094.

Zahra, S.A. and George, G., 2002, Absorptive capacity: A review, re-conceptualization, and extension, Academy of Management Review, 27 (2): 185-203. 


\section{Appendix 1. Findings from rough set analysis}

Summary of results of the rough set analysis

\begin{tabular}{|l|c|l|}
\hline Condition attribute & $\begin{array}{l}\text { Overall frequency } \\
\text { in rules }\end{array}$ & $\begin{array}{l}\text { Frequency in } \\
\text { rules of global } \\
\text { networks only }\end{array}$ \\
\hline $\mathrm{C}_{1}$ Main activity & 2 & 1 \\
\hline $\mathrm{C}_{2}$ Duration of innovation projects & 3 & 2 \\
\hline $\mathrm{C}_{3}$ Spatial focus in overall strategy & 6 & 2 \\
\hline $\mathrm{C}_{4}$ Age & 3 & 2 \\
\hline $\mathrm{C}_{5}$ Size & 3 & 1 \\
\hline $\mathrm{C}_{6}$ Position & 5 & 3 \\
\hline Indicators of strength of the information table b) & & \\
\hline Number of core variables & 5 out of 6 & \\
\hline Quality of the core & 1.0 & \\
\hline & & \\
\hline Indicator of strength of the results & & \\
\hline Maximal coverage of rules & $41.7 \%$ & \\
\hline Majority of coverage (4) & $22.2 \%$ & \\
\hline
\end{tabular}

a) In brackets: frequency concerning global networks.

b) Size does not belong to the core. If all condition attributes belong to the core, then all of them contribute to an explanation and no attribute gives redundant information. Further, the value of 1.0 for the quality of the core means that the reliability of the classification for the dependent variable and the overall quality of the information table are at their maximum.

Source: Adapted from van Geenhuizen (2005, 2008b) 
Appendix 2 A matrix of global knowledge firms

\begin{tabular}{|c|c|c|}
\hline $\begin{array}{l}\text { Enabling/driving } \\
\text { factors of global } \\
\text { knowledge gaining }\end{array}$ & $\begin{array}{l}\text { Category of companies } \\
\text { and level of virtualization }\end{array}$ & $\begin{array}{l}\text { Loss of importance of local } \\
\text { networks }\end{array}$ \\
\hline $\begin{array}{l}\text { Older (age) and } \\
\text { long innovation } \\
\text { projects (Rule 7) }\end{array}$ & $\begin{array}{l}\text { Biotechnology research: low } \\
\text { level of virtualization } \\
\text { Optronics research and } \\
\text { manufacturing: high level of } \\
\text { virtualization }\end{array}$ & 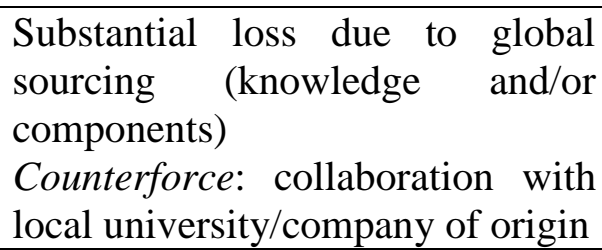 \\
\hline $\begin{array}{ll}\text { Foreign } & \text { subsidiary } \\
\text { and } & \text { indifferent } \\
\text { spatial focus in } \\
\text { strategy (Rule 5) }\end{array}$ & $\begin{array}{l}\text { Telecom: high level of } \\
\text { virtualization } \\
\text { ICT advanced services: } \\
\text { lower level of virtualization }\end{array}$ & $\begin{array}{l}\text { No substantial loss, due to local } \\
\text { customer market relations }\end{array}$ \\
\hline $\begin{array}{l}\text { Corporate spin-off } \\
\text { and advanced } \\
\text { services (Rule 6) }\end{array}$ & $\begin{array}{l}\text { Biotechnology advanced } \\
\text { (customized) services: high } \\
\text { level of virtualization }\end{array}$ & $\begin{array}{l}\text { No substantial loss, due to } \\
\text { collaboration with local company } \\
\text { of origin }\end{array}$ \\
\hline $\begin{array}{l}\text { Age (young) and } \\
\text { global focus in } \\
\text { strategy (Rule 8) }\end{array}$ & $\begin{array}{l}\text { Biotechnology research: } \\
\text { low/ high level of } \\
\text { virtualization } \\
\text { Advanced telecom services } \\
\text { ('born global'): high level of } \\
\text { virtualization }\end{array}$ & $\begin{array}{l}\text { Substantial loss after turning } \\
\text { global in all aspects as a } \\
\text { subsidiary (particularly 'reversed' } \\
\text { knowledge transfer) }\end{array}$ \\
\hline
\end{tabular}

